\title{
The Survey of Tendency in Learning Styles of Fifth Grade Elementary School Students in Cluster Three of Gunungsari Sub-Districts
}

\author{
Ade Andriyan \\ Faculty of Psychology \\ Universitas Airlangga \\ Surabaya, Indonesia \\ ade.andriyan- \\ 2020@psikologi.unair.ac.id
}

\author{
Muhammad Yamin \\ Faculty of Teacher Training and \\ Education \\ University of Mataram \\ Mataram, Indonesia \\ muhammadyamin@gmail.com
}

\author{
Arina Hidayati \\ SMPN 1 Gunungsari \\ Gunungsari, Indonesia \\ arinahidayati68@gmail.com
}

\author{
Andra Ade Riyanto* \\ Faculty of Teacher Training and \\ Education \\ University of Mataram \\ Mataram, Indonesia \\ andra.riyanto@unram.ac.id
}

\author{
La Ode Alfin Haris Munandar \\ Faculty of Teacher Training and \\ Education \\ University of Mataram \\ Mataram, Indonesia \\ laode_alfinharis@unram.ac.id
}

\begin{abstract}
This study aims to determine the tendency of learning styles possessed by fifth-grade primary school students in cluster 3 Gunungsari sub-district in 2018/2019. This research is a type of quantitative research using survey methods. The type of survey used in this study is a cross-sectional type. The variables in this study are learning styles which include visual, auditory, and kinesthetic. The population in this study were all fifth-grade primary school students in cluster 3 of Gunungsari sub-district in 2018/2019. The sample used as many as 52 students with sampling was conducted by probability sampling technique using proportional simple random sampling. The technique of collecting data uses a closed questionnaire. The analysis technique used is descriptive statistics. The results showed that every fifth-grade primary school student in cluster 3 Gunungsari sub-district in 2018/2019 tended to one of the visual, auditory, or kinesthetic learning styles. The majority of students have a tendency to visual learning styles with percentage details of $53.85 \%$, while $34.61 \%$ of students have a tendency toward auditory learning styles, and $11.54 \%$ of students have a tendency to kinesthetic learning styles.
\end{abstract}

Keywords—student learning styles, visual, auditory, kinesthetic.

\section{INTRODUCTION}

Students as individual beings have a unique diversity of characteristics. Each individual has certain characteristics that differentiate them from other individuals. Individual characteristics include several basic properties inherent in certain individuals, both psychic and physical. Based on the psychological aspect, each individual has differences in the level of intelligence, ability, interest, memory, emotions, will, personality, and so on. While the physical aspect includes shape, size, strength, and endurance. Regarding the learning process, Slavin [1] stated that each student has different levels of performance, learning speed, and learning style. There are slow and some are fast learning. The difference also occurs in learning styles. As for the method chosen, differences in learning styles show that the fastest and best way for each individual to be able to understand the information from outside themselves.

Learning style is one of the important aspects that must be considered by teachers and students. The importance of teachers knowing the learning styles of all their students is based on ineffective learning in the classroom. Musrofi in Pratiwi [2] said that only $30 \%$ of students succeeded in participating in learning because they had a learning style that was in accordance with the teaching style applied by the teacher in the classroom. The rest, as many as $70 \%$ of students get difficulties in following the learning process in the classroom. This is because they have other learning styles that are incompatible with the teaching styles applied in the classroom. This means that there are still many students who have not been accommodated in the learning process properly because of the teacher's teaching style or strategy in learning.

Based on the results of an interview with fifth-grade teachers at primary school 1 Tamansari on March 5, 2018, the teachers admitted that they did not know the learning styles of all their students. The teacher knows that each student has a different learning style but has never identified the learning style that each student has. During this time, students just follow the learning process with methods that have been defined by the teacher. Also, researchers have conducted interviews with four fifth-grade students of primary school 1 Tamansari on March 5, 2018. From the results of the interview, the four students were able to tell their study habits well but answered hesitantly when asked about their favorite learning style. Therefore, it can be said that there are still many students who do not yet know their favorite learning style.

Based on the learning style problem above, the researcher is interested in knowing the learning style tendency of fifthgrade primary school students in Gunungsari sub-district. Researchers chose Gunungsari sub-district as the research subject because in this sub-district a similar study had never been conducted. The researcher chooses fifth-grade with the consideration that they will soon be prepared for the national 
exam. This research is expected to help teachers understand the learning styles of each student.

\section{LITERATURE REVIEW}

The ability of students to understand and comprehend the lessons is definitely of different levels. There are fast, moderate, and some are very slow. Therefore, they often have to take different ways to understand the information or lessons. This different way is a typical learning method for students which is called a learning style [3]. Learning styles are the way students tend to react and use stimuli in comprehending and organizing and processing information in the learning process. Therefore, a student's learning style is always shown by each student and will show different learning styles in the learning process.

Based on sensory preferences or the ability of the brain to understand, manage and convey information, individual learning styles can be divided into 3 (three) categories. The three categories are visual, auditory, and kinesthetic learning styles. Visual learning styles rely on the sense of sight in learning. Auditory learning styles rely on the sense of hearing in learning. Kinesthetic learning styles rely on active movement, conduct, and manipulation in learning. The three kinds of learning styles have characteristics that are unique to each other [4].

\section{A. Visual Learning Style}

A visual learning style is someone who learns by seeing. Believe what they saw, either in the form of numbers, objects, or colors. Deporter and Hernacki [4] said that visual learning style is learning by seeing which has the following characteristics:

a) Neat and orderly,

b) Speak quickly,

c) Able to plan and manage for the long term,

d) Thorough and detailed,

e) Concerned with appearance,

f) It is easier to remember what was seen than what was heard,

g) Remembering something based on visual associations,

h) Can spell letters very well,

i) Prefer to demonstrate something rather than give a speech/lecture,

j) More interested in art (painting, sculpture, drawing) than in music, and others.

\section{B. Auditory Learning Style}

Deporter and Hernacki [4] explained that the auditory learning style is a learning style by listening which has the following characteristics:

a) Often talk to themselves while working (studying),

b) Easily distracted by noise,

c) Move lips and say the words in the book when reading,

d) Prefer to listening than reading,

e) If you read, you prefer to read aloud,

f) Can repeat or imitate the tone, rhythm, and color of the voice,

g) Has difficulty in writing some things, but is very good in telling stories,

h) Speaking in a well-patterned rhythm, i) Speak very fluently,

j) Prefer the art of music than other arts,

k) Enjoys talking, discussing, and explaining something in length,

1) Having difficulty when faced with tasks related to visualization, and others

\section{Kinesthetic Learning Style}

Deporter and Hernacki [4] mention the characteristics of people who have a kinesthetic learning style as follows:

a) Speak slowly,

b) Responding to physical attention,

c) Touching others to get their attention,

d) Stand close when talking to other people,

e) A lot of physical movement,

f) Learning through direct practice or manipulation,

g) Memorizing something by walking or seeing directly, and so on.

\section{METHODS}

The type of this research is quantitative research. Quantitative research is a type of research that systematic, well-planned, and structured from the start to the making of the research design [5]. This study uses a survey method that aims to make it easier to obtain information about several respondents who are considered to represent a certain population by using a questionnaire as an instrument for data collection. The type of survey used in this study is a crosssectional type because the assessment in this study is to describe [6].

The research was conducted in the second semester of the Academic Year 2018/2019, ie from March-April 2019. This research was conducted in primary school as Cluster 3 in Gunungsari sub-district, totaling five primary schools including SDN 1 Midang, SDN 2 Midang, SDN 3 Midang, SDN 1 Kekeri, and SDN 2 Kekeri. The population in this study included all students of grade fifth primary school as Cluster 3 in Gunungsari sub-district with a total of 207 students, consisting of 118 male students and 89 female students. Based on the population, the sample taken for this study was $25 \%$ with a total of 52 people. Sampling was conducted by using probability sampling technique using proportional simple random sampling.

The data in this study were primary and sourced from the learning styles shown in the learning activities of fifth-grade students at primary school in Cluster 3 Gunungsari subdistrict. While the data collection technique in this study used an instrument in the form of a questionnaire. The use of a questionnaire in this study was chosen because this data collection technique is more efficient when used to reach many data sources. Also, the type of questionnaire used is a closed questionnaire.

The data analysis technique in this research is the descriptive statistical analysis method and single data distribution mode analysis. Descriptive statistical analysis is used to analyze data by describing the data that has been collected without intending to make general conclusions or generalizations. While the single data distribution mode analysis is used to find answers that often appear or the value that has the most frequency from respondents in filling out a questionnaire about the learning style trends of fifth-grade 
students. This questionnaire is in the form of multiple choices which has a total of 13 items, each of which has three aspects of learning style, namely visual, auditory, and kinesthetic. The highest score for each learning style is 13 . The scores obtained will be grouped into visual, auditory, and kinesthetic aspects. The scores that are included in the same aspect will be added up and the comparison is seen.

\section{RESULTS AND DISCUSSION}

\section{A. Results}

\section{Student Learning Style}

Based on the results of the questionnaire data analysis of students' learning styles, it can be seen that as many as 28 students tend towards visual learning styles, 18 students have a tendency towards an auditory learning style, and 6 other students have a tendency towards a kinesthetic learning style. A summary of the results of data analysis on student learning styles can be seen in the following table.

TABLE I. THE RESULTS OF THE ANALYSIS OF STUDENTS LEARNING STYLE TRENDS

\begin{tabular}{|c|c|c|c|c|}
\hline & \multicolumn{3}{|c|}{ Learning Style } & Total sample \\
\cline { 2 - 4 } & Visual & Auditory & Kinesthetic & \\
\hline $\begin{array}{c}\text { The number of } \\
\text { students }\end{array}$ & 28 & 18 & 6 & 52 \\
\hline Percentage & $53.85 \%$ & $34.61 \%$ & $11.54 \%$ & $100 \%$ \\
\hline
\end{tabular}

If it is depicted in the form of a pie chart, the frequency of students who tend towards visual, auditory, and kinesthetic learning styles will appear as follows.

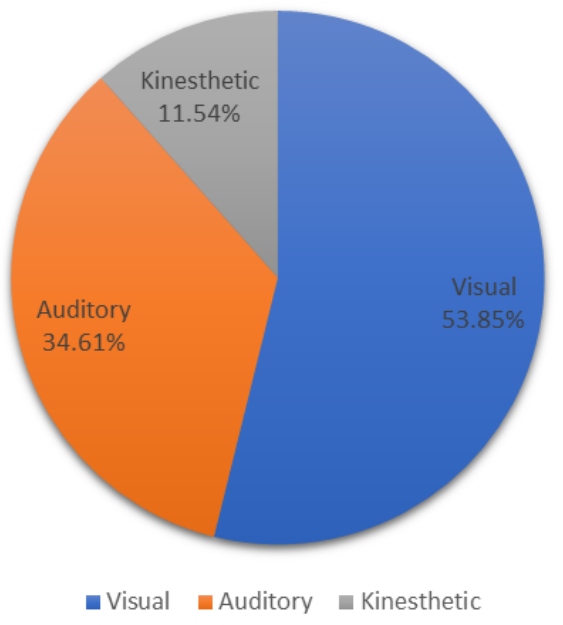

Fig. 1. Frequency Diagram of Student Learning Style Tendency

\section{Comparison of Learning Styles Based on Gender}

Based on the results of the learning style research that has been carried out on a sample of 52 students, it is known that 26 students are male. Of the 26 male students, 16 of them had a visual learning style tendency with a percentage of $61.54 \%$, 7 students tended towards an auditory learning style with a percentage of $26.92 \%$, and 3 other students had a kinesthetic learning style tendency with a percentage of $11.54 \%$. The summary of the results of data analysis on male students' learning styles can be seen in the following table.

TABLE II. ANALYSIS OF MALE STUDENT LEARNING STYLES TRENDS

\begin{tabular}{|c|c|c|c|c|}
\hline & \multicolumn{3}{|c|}{ Learning Style } & $\begin{array}{c}\text { Total sample } \\
\text { (male } \\
\text { students) }\end{array}$ \\
\cline { 2 - 4 } & Visual & Auditory & Kinesthetic & 26 \\
\hline $\begin{array}{c}\text { The number of } \\
\text { students }\end{array}$ & 16 & 7 & 3 & $100 \%$ \\
\hline Percentage & $61.54 \%$ & $26.92 \%$ & $11.54 \%$ & \\
\hline
\end{tabular}

The visual display of the frequency of male student learning styles can be seen in the following diagram.

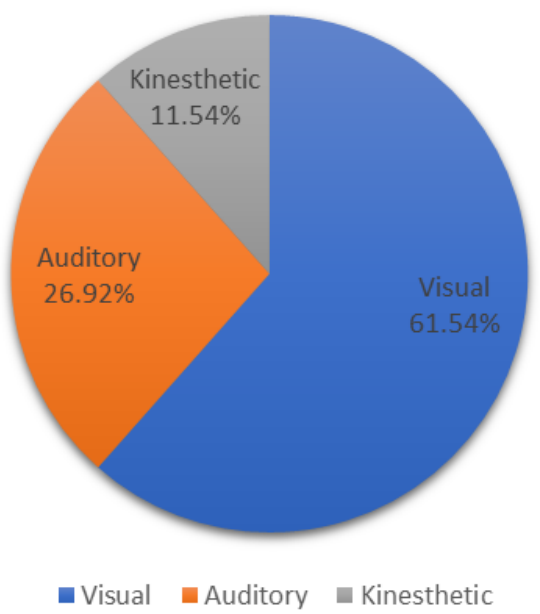

Fig. 2. Frequency Diagram of Male Student Learning Style Tendency

Based on the results of the learning style research that has been carried out on a sample of 52 students, it is known that 26 students are female. Of the 26 female students, 12 of them had a visual learning style tendency with a percentage of $46.15 \%, 11$ students tended towards an auditory learning style with a percentage of $42.31 \%$, and 3 other students tended towards kinesthetic learning style with a percentage of $11.54 \%$.

TABLE III. ANALYSIS OF FEMALE STUDENT LEARNING STYLES TRENDS

\begin{tabular}{|c|c|c|c|c|}
\hline & \multicolumn{3}{|c|}{ Learning Style } & \multirow{2}{*}{\begin{tabular}{|c|} 
Total \\
sample \\
(female \\
students)
\end{tabular}} \\
\hline & Visual & Auditorial & Kinesthetic & \\
\hline $\begin{array}{c}\text { The number of } \\
\text { students }\end{array}$ & 12 & 11 & 3 & 26 \\
\hline Percentage & $46.15 \%$ & $42.31 \%$ & $11.54 \%$ & $100 \%$ \\
\hline
\end{tabular}

The visual display of the frequency of female student learning styles can be seen in the following diagram. 


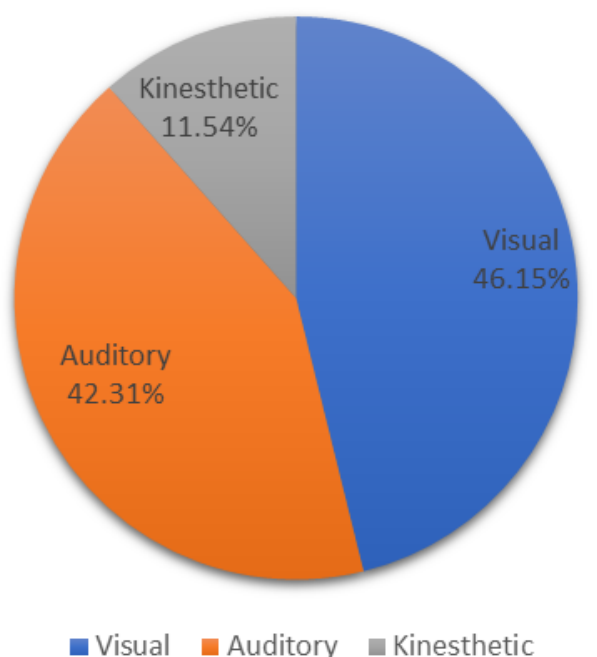

Fig. 3. Frequency Diagram of Female Student Learning Style Tendency

The learning styles of male and female students at SDN Gugus 3 Gunungsari District have a ratio of $61.54 \%$ to $46.15 \%$ in the visual learning style aspect. Then in the aspect of auditory learning styles, male and female students of SDN Gugus 3 Gunungsari District had a ratio of $26.92 \%$ to $42.31 \%$. Meanwhile, in the kinesthetic learning style aspect, male and female students at SDN Gugus 3 Gunungsari District had the same percentage, namely $11.54 \%$. The results of the student learning style questionnaire data are presented in the following figure.

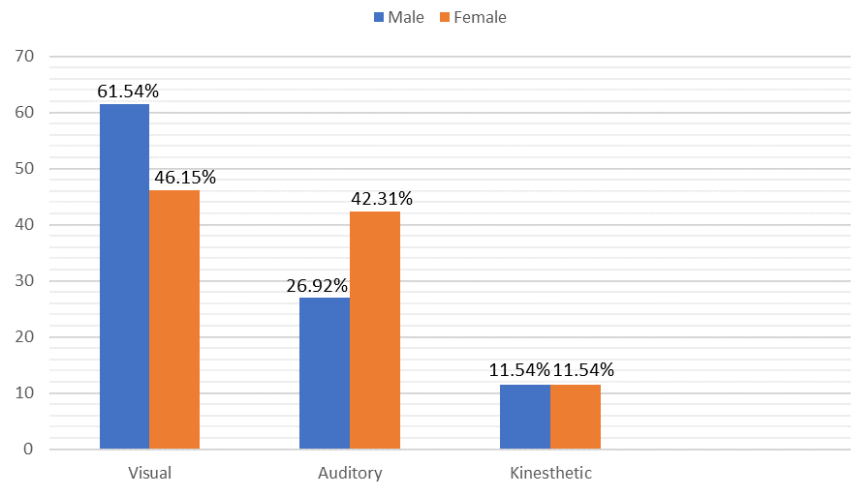

Fig. 4. Frequency Diagram Comparison of Student Learning Styles

\section{B. Discussion}

Based on the data analysis that has been analyzed, it was found that of the 52 fifth grade students of primary school cluster 3 Gunungsari sub-district 28 of them or about $53.85 \%$ tended to have a visual learning style. This means that most of the fifth-grade students of primary school cluster 3 Gunungsari sub-district find it easier to understand their lessons through what they see, whether they are numbers, objects, colors, or pictorial material. Also, students who learn with a visual learning style have other characteristics such as neat and orderly, speak quickly, students become quick and diligent readers, prefer reading rather than being read out, like to make meaningless scribbles during speaking, often answer questions. In short, they prefer to demonstrate something rather than give speeches, more interested in the field of fine arts than music, and so on.

However, students with visual styles will usually get difficulties when doing oral activities such as difficulty remembering, difficulty understanding spoken words, or following verbal recommendations so they often misinterpret [4]. It will also be difficult for them to have a direct dialogue to express what they want to convey orally. Even so, this visual learning style can be applied in learning using several approaches. For example, by using various forms of graphics to convey information/subject matter in the form of films, slides, illustrations, scribbles, or serial picture cards to explain information sequentially.

Furthermore, as many as 18 or about $34.61 \%$ of students tend towards auditory learning styles. The characteristics of students who have this learning style rely on hearing as the primary ability to obtain information or knowledge. Students with auditory learning styles also getting speaking skills. This is following other characteristics of auditory learners, which are speaking in a well-patterned rhythm, speaking very fluently, preferring music to fine art, easily distracted by noise, happy to talk, discuss and explain something at length, like to read aloud, and so on.

Even though students or auditory learners are good speakers, they will have difficulty if they have to work related to visuals ability. The obstacles in this auditory learning style are students often forget or make mistakes about the teacher's explanation. Students who like auditory learning styles generally do not like to read the instruction manual. They prefer to ask to get the information needed. Therefore, several approaches can be done to overcome these learning difficulties. First, use a tape recorder as a recording tool that functions to record the reading or notes that the teacher reads in front of the classroom so that they can be heard again. Second, conducting interviews or being actively involved in group discussions. Third, by trying to read information which is then summarized in oral form and recorded for listening or re-understanding.

Meanwhile, as many as 6 or about $11.54 \%$ of the other students tend towards kinesthetic learning styles. Students with the kinesthetic learning style are characterized by speaking slowly, responding to physical attention, touching others to get their attention, standing close when talking to others, a lot of physical movement, learning through direct practice or manipulation, memorizing things by walking, and others. Also, kinesthetic learners are more active because in receiving the information they often use their fingers to point to the word being read while reading, use a lot of body language (non-verbal), unable to sit quietly for long periods, generally has bad writing, likes activities or games that involve physic, and wants to do everything. To apply it in the learning process to students who have kinesthetic characteristics, it can be conducted by using various models, for example studying in the lab or allocating time during the learning process which allows them to play. Based on the description above, it is known that students will be more likely to choose one of the three learning styles according to their learning style.

Based on gender, male students of fifth-grade primary 
school cluster 3 Gunungsari sub-district have a visual style tendency of $61.54 \%$, auditory style of $26.92 \%$, and kinesthetic style of $11.54 \%$. From the three learning styles, the frequency of students who tend to use visual styles is more than students who use auditory and kinesthetic styles. Based on these results, it can be concluded that the fifth-grade male students of primary school cluster 3 Gunungsari sub-district mostly tend to learn in a visual style, which is $61.54 \%$. Students tend to learn by seeing directly, for example by reading material. Students will also be pleased if the teacher provides learning material through the media in the form of pictures or something that can be visualized. This result is in accordance with research from Halpern in Santrock [7] which stated that male students have higher visual-spatial skills than female students. These skills include sensitivity to colors, lines, shapes, spaces, and the relationships between these elements so that, male students will more quickly understand the material shown through the media of images or other visual media. Also, in terms of discipline and attention, male students showed less prosocial behavior and empathy so that male students tended to be lazy to listen to material explanations.

Then the fifth-grade female students of primary school cluster 3 Gunungsari sub-district have a visual learning style tendency of $46.15 \%$, auditory learning style of $42.31 \%$, and kinesthetic learning style of $11.54 \%$. From the three learning styles, the frequency of students who tend to use visual styles is more than students who use auditory and kinesthetic styles. Based on these results, it can be concluded that the fifth-grade female students of primary school cluster 3 Gunungsari subdistrict mostly tend to learn in a visual style, which is $46.15 \%$. However, the tendency of female students' auditory learning styles was higher than male students with a ratio of $42.31 \%$ to $26.92 \%$. This proves that female students tend to prefer to learn how to listen to the teacher's explanation and conducted discussion activities than male students. Students with auditory learning styles will usually find it difficult if they receive material only through writing or pictures. Therefore, they need someone who can explain in detail. This result is also in accordance with research from Maccoby and Facklin in Santrock [7] which stated that based on psychological factors, the brain area that functions for language and communication skills and controls women's sense of hearing is greater than men. Several studies have also found that academically, female students are better at verbal skills so that, female students will stand out more in discussions and be able to understand the verbal instructions well.

\section{CONCLUSION}

Based on the results of data analysis and discussion, it can be concluded that the fifth-grade students of primary school cluster 3 Gunungsari sub-district tend towards visual learning styles of $53.85 \%$, auditory learning styles of $34.61 \%$, and kinesthetic learning styles of $11.54 \%$. Based on students' gender, male and female students at fifth-grade students of primary school cluster 3 Gunungsari sub-district have a ratio of $61.54 \%$ to $46.15 \%$ in the aspect of visual learning styles. On the aspect of auditory learning styles had a ratio of $26.92 \%$ to $42.31 \%$. Meanwhile, the kinesthetic learning style aspect had the same percentage, which is $11.54 \%$.

\section{REFERENCES}

[1] R. E. Slavin, Psikologi Pendidikan: Teori dan Praktik. Jakarta: PT Indeks, 2011.

[2] D. Pratiwi, "Gaya Belajar Dominan pada Siswa Berprestasi dalam Kegiatan Siswa yang memiliki gaya belajaran di SD Negeri 2 Gombong Tahun Ajaran 2013/2014," Jurnal FKIP, vol 7, no. 3, 2014.

[3] W. S. Winkel, Psikologi Pengajaran. Jakarta: Grasindo, 2009

[4] B. Deporter and M. Hernacki, Quantum learning. Yogyakarta: Kaifa, 1999.

[5] S. Sugiyono, Metode Penelitian Kuantitatif, Kualitatif, dan R\&D. Bandung: Alfabeta, 2017.

[6] J. W. Creswell, Educational research. Boston: Pearson Education, 2012

[7] J. W. Santrock, Perkembangan Anak. Jakarta: Erlangga, 2009. 